\title{
The role of bisphenol $A$ and its analogues as endocrine disruptors influencing the thyroid gland: a short review
}

\author{
Justyna Milczarek-Banach \\ Department of Internal Medicine and Endocrinology, \\ Medical University of Warsaw \\ (iD) https://orcid.org/0000-0001-6548-6118

\section{Piotr Miśkiewicz} \\ Department of Internal Medicine and Endocrinology, \\ Medical University of Warsaw \\ (D) https://orcid.org/0000-0003-4015-6491 \\ Corresponding author: piotr.miskiewicz@wum.edu.pl
}

DOI: https://doi.org/10.20883/medical.e441

\begin{abstract}
Keywords: bisphenol A, thyroid, hypothyroidism, endocrine disrupting chemical, plastic, autoimmunity
\end{abstract}

Published: 2020-09-30

\begin{abstract}
How to cite: Milczarek-Banach J, Miśkiewicz P. The role of bisphenol $A$ and its analogues as endocrine disruptors influencing the thyroid gland: a short review. JMS [Internet]. 2020 Sep 30;89(3):e441. doi:10.20883/medical.e441
\end{abstract}

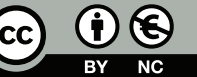

(C) 2020 by the author(s). This is an open access article distributed under the terms and conditions of the Creative Commons Attribution (CC BY-NC) licencse. Published by Poznan University of Medical Sciences

\begin{abstract}
Bisphenols (BPs) are common plastic additives widely used in industry, hence, human exposure to BPs is inevitable. The best known BP is bisphenol A (BPA), the production of which and its analogues has been increasing worldwide. This chemical is classified as an endocrine-disrupting chemical, inferring with hormonal homeostasis. Indeed, BPA is associated with the development of oestrogen-dependent neoplasms, infertility, metabolic disorders and neurobehavioral disturbances. However, there is a lack of evidence regarding the impact of BPA and its analogues on the thyroid, with most studies mainly performed on animals or in vitro. This review aims to summarise the knowledge regarding the relationship between BPA and its analogues on the thyroid gland.
\end{abstract}

\section{Introduction}

Bisphenols (BPs) are common plastic additives widely used in industry. They are products in the manufacture of polycarbonate plastics, such as water bottles, toys, food boxes, teethers, baby pacifiers, thermal paper, inner linings of beverage and food containers, dental sealants, epoxy resins [1-6]. People are exposed to BPs mainly due to contaminated food, especially in high temperatures or acidic conditions $[6,7]$. Nonetheless, the other possibilities of exposure to BPs include transdermal or inhalation routes [8].
The most common BP is bisphenol A (BPA; $4,4^{\prime}$-isopropylidenediphenol), which is composed of two benzene rings and two 4,4'-OH substituents (Figure 1). Since its industrial application, many studies have revealed the harmful effects of this chemical on human health, especially on hormonal homeostasis. Subsequently, BPA has been classified as an endocrine-disrupting chemical (EDC) [5, 9-11]. BPs act as xenoestrogens, impacting the development of oestrogen-dependent neoplasms (e.g., breast or endometrial cancers) [12-14], as well as being associated with infertility [15] and polycystic ovary syndrome [16]. More- 


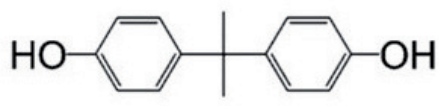

Bisphenol A (BPA)<smiles>N[C@@H](Cc1cc(I)c(Oc2cc(I)c(O)c(I)c2)c(I)c1)C(=O)O</smiles>

Thyroxine

(T4)<smiles>N[C@@H](Cc1cc(I)c(Oc2ccc(O)c(I)c2)c(I)c1)C(=O)O</smiles>

Triiodothyronine (T3)

Figure 1. Chemical structures of bisphenol A, thyroxine and triiodothyronine

over, BPA may contribute to the development of metabolic disorders (e.g., insulin resistance, diabetes, obesity) [17] and neurobehavioral disturbances [18]. Furthermore, the specific molecular structure that mimics thyroid hormones allows BPA to influence thyroid hormone homeostasis [19-21] but most of these studies were conducted in vitro $[19,22,23]$ or on animals $[24,25]$.

\section{Types of BPA analogues}

Since the use of BPA in products for children has been prohibited, the large-scale production of BPA analogues has escalated. Ideally, substitutes intended to replace a specific chemical should be less toxic than the original substance. Unfortunately, many chemical replacements introduced into the industry have never been studied and are often more harmful than the original chemical.

BPA analogues are compounds with a chemical structure similar to BPA, which means they include at least two phenyl rings, but their substituents differ depending on the type of the analogue (i.e., methyl, bromine or chlorine substituents in 3,3 ' or 3,5-positions of the phenyl rings). BPA analogues include bisphenol $F$ (BPF), bisphenol $B(B P B)$, bisphenol Z (BPZ), bisphenol C (BPC), bisphenol $P$ (BPP), bisphenol M (BPM), bisphenol AP (BPAP), bisphenol AF (BPAF), bisphenol AD (BPAD), tetrabromobisphenol A (TBBPA), tetrachlorobisphenol A (TCBPA), tetramethylbisphenol A (TMBPA), and dimethylbisphenol A (DMBPA) [19, 22, 23, 26].

\section{Metabolism of BPA}

After oral consumption, BPA undergoes firstpass metabolism in the intestine and liver, then it is metabolised by UDP-glucuronosyltransferase in the liver. After glucuronidation, BPA is eliminated via renal clearance within 24 hours [27]. Nonetheless, there is a concern about the other routes of human exposure to BPA, mainly via inhalation or transdermally, which bypass the first pass in the gastrointestinal tract, hence there is a longer exposure to unconjugated BPA. It is well documented in the literature that BPA is ubiquitous and has been measured in a variety of human body fluids [28] including placenta, maternal milk and amniotic fluid [29,30]. The detection rates of BPs differ according to the detection method used (LC-MS, GC-MS, HPLC, HPLS-MS/MS) and the form of BPs (conjugated, unconjugated or total). Importantly, there is a lack of information regarding the metabolism of BPA analogues in humans.

\section{Mechanisms of action of BPs on the thyroid}

BPs can interact with the thyroid gland via a variety of routes, therefore, the potential crosstalk needs to be considered at multiple levels. BPA is the first environmental chemical known to bind to the thyroid receptor (TR) and affect thyroid hormone homeostasis in vitro [25]. Lee et al. [22], as well as Moriyama et al. [21], suggested that BPA can influence thyroid hormones at the transcriptional level. Moreover, Schmutzler et al. [31] reported that BPA interferes with thyroid function by inhibiting recombinant thyroid peroxidase (TPO) activity. Furthermore, an in vitro study of Kudo et al. [32] found the antagonistic ability of BPA derivatives to triiodothyronine (T3) in binding to transthyretin (TTR), which is the transport protein for thyroid hormones. 


\section{Influence of BPs on thy- roid function}

The results regarding the influence of BPs on thyroid function are conflicting and depend on the study design (in vivo or in vitro) and the examined group (human, animals, cell lines). According to in vitro studies of rat pituitary (GH3) cells, BPs (BPA, BPAF, $B P A P, B P B, B P C, B P F, B P M, B P P, B P Z$ ) have an agonistic effect on thyroid hormones, which is doseand time-dependent [23]. Co-exposure of $\mathrm{GH} 3$ cells to $17 \beta$-oestradiol enhanced this effect. Similarly, in another study [22] on rat pituitary (GH3) and thyroid follicular (FRTL-5) cells, the authors suggested that the results were different according to cell type, with $B P A$ and its analogues (BPAF, BPAP, BPB, BPF, $B P M, B P P, B P S, B P Z, B P C)$ significantly downregulating tsh $\beta$, tra, $\operatorname{tr} \beta$, diol or dio2 genes in $\mathrm{GH} 3$ cells, whereas in FRTL- 5 cells, the genes responsible for hormone synthesis were upregulated. Furthermore, in the first in vitro study on the influence of BPA on thyroid [21], BPA antagonised T3 action at the transcriptional level in a dose-dependent manner. Kitamura et al. [19] reported that in the rat pituitary cell line $\mathrm{GH} 3$, selected $\mathrm{BPs}$ exhibited thyroid hormonal activity (TBBPA, TCBPA, TMBPA), while others (BPA, BPF, BPS, BPAF, BPAD, BPB, DMBPA) did not show such effect. The authors suggested that the chemical structure (the type of substituents of the phenyl rings of BPs) is crucial for the thyroid hormonal activity, particularly, hydroxyl groups in 4,4'positions and methyl, bromine or chlorine in 3,3 ', 5 and 5 '-positions of the phenyl rings.

The results of the animal studies are inconsistent. Perinatal exposure to BPA in pups [33] or adult polecats [34] did not show any statistically significant influence on thyroid hormones, whereas there was a positive relationship between concentrations of BPA and thyroxine (T4) levels in rats [25]. Also, Lee et al. [26] demonstrated that selected BPs disrupted thyroid hormone levels by increasing T3 and T4 in embryo-larval zebrafish, suggesting that the potency of BPA analogues could be even stronger than that of BPA. It is of note that BPA derivatives could be more harmful than BPA as they act in much lower concentrations than BPA itself.

Regarding human studies, the data considering the relationship between BPs and thyrotropin (TSH) and T4 are conflicting. According to correlations between TSH and BPs in humans, there is an inverse relationship in both sexes [35] and only in women [36], suggesting that exposure to BPs may lead to the development of hyperthyroidism. Also, Meeker et al. [37] measured BPA concentrations in the urine of 1346 adults and 329 adolescents (aged 1-19 years) from the National Health and Nutrition Examination Survey (NHANES) in the period 20072008 , observing a suggestive inverse association (but without statistical significance) between urinary BPA and TSH. In contrast, Andrianou et al. [28] suggested a positive correlation between BPA with its derivatives and TSH, which could lead to the development of hypothyroidism. Furthermore, there was a positive association between urinary BPA and serum TSH in lean individuals [38]. Taking into the consideration that BPs influence thyroid hormones in humans, the authors of several studies in pregnant women reported that BPA levels were positively [35] or inversely [20] correlated with maternal T4 levels, with two other studies found no association [36, 39].

\section{BPs influence on the forma- tion of thyroid nodules}

Nodular goitre and thyroid cancer are related to endogenous oestrogen activity [40-42], hence, as a xenoestrogen, BPA could impact the formation of thyroid nodules. Zhou et al. [43] showed that higher BPA concentrations in urine are potentially linked to the genesis of nodular goitre and papillary thyroid carcinoma (PTC), with women with nodular goitre and PTC having higher concentrations of BPA than men. Moreover, females from the PTC group presented lower urinary BPA levels than those of the nodular goitre group. Furthermore, Marotta et al. [44] described a dose-independent correlation between BPAF and the risk of development of differentiated thyroid cancer in subjects with thyroid nodules. Li et al. [45] also showed a significant association between BPA and a higher risk of thyroid nodules in Chinese women, but only in subjects with positive TgAb and TPOAb, whereas Wang et al. [46] observed a negative correlation between urinary BPA and the risk of forming multinodular goitre, but not of solitary thyroid nodules in schoolchildren. In another study, Andrianou et al. [28] reported no association between BPs and higher risk of thyroid nodules in adult females. 


\section{BPs influence on autoim- mune thyroid disease}

Several studies have assessed the relationship between BPA and the development of autoimmune diseases, including autoimmune thyroid disease [47-49]. BPA can affect the immune system directly and indirectly [50]. Özaydın et al. [48] proved the influence of BPA on the alteration of immune parameters, such as cytokine profile and the distribution of $\mathrm{CD}^{+}$and $\mathrm{CD} 4^{+} \mathrm{T}$ lymphocytes in rats which can result in the development of immunodeficiencies and autoimmune diseases. Also, two case reports described the possible relationships between BPA exposure and immune system-related diseases [51, 52]. Chailurkit et al. [47] also documented the independent, statistically significant association between BPA and thyroid peroxidase antibodies (TPOAb).

\section{Conclusions}

In conclusion, the results of the studies concerning the impact of BPs on the thyroid are conflicting and are dependent on the study design and the detection methods used. It seems that BPA derivatives could be even more harmful to humans than BPA as they could act in much lower concentrations than BPA itself. As the exposure to these endocrine disruptors is inevitable, there is a strong need for large randomised human trials to establish the potentially detrimental effects of BPA and its analogues before their industrial application.

\section{Acknowledgements}

\section{Conflict of interest statement}

The authors declare no conflict of interest.

\section{Funding sources}

There are no sources of funding to declare.

\section{References}

1. Braun JM, Hauser R. Bisphenol A and children's health. Current Opinion in Pediatrics. 2011 Apr;23(2):233-239. https://doi.org/10.1097/mop.0b013e3283445675

2. Carwile JL, Luu HT, Bassett LS, Driscoll DA, Yuan C, Chang JY, Ye X, Calafat AM, Michels KB. Polycarbonate Bottle Use and Urinary Bisphenol A Concentrations. Environmental Health Perspectives. 2009 Sep;117(9):1368-1372. https://doi.org/10.1289/ ehp.0900604
3. Fenichel P, Chevalier N, Brucker-Davis F. Bisphenol A: An endocrine and metabolic disruptor. Annales d'Endocrinologie. 2013 Jul;74(3):211-220. https://doi. org/10.1016/j.ando.2013.04.002

4. Geens T, Goeyens L, Kannan K, Neels H, Covaci A. Levels of bisphenol-A in thermal paper receipts from Belgium and estimation of human exposure. Science of The Total Environment. 2012 Oct;435-436:30-33. https://doi.org/10.1016/j.scitotenv.2012.07.001

5. Hehn RS. NHANES Data Support Link between Handling of Thermal Paper Receipts and Increased Urinary Bisphenol A Excretion. Environmental Science \& Technology. 2015 Dec 17;50(1):397-404. https://doi. org/10.1021/acs.est.5b04059

6. Rubin BS. Bisphenol A: An endocrine disruptor with widespread exposure and multiple effects. The Journal of Steroid Biochemistry and Molecular Biology. 2011 Oct;127(1-2):27-34. https://doi.org/10.1016/j. jsbmb.2011.05.002

7. Geens T, Aerts D, Berthot C, Bourguignon J, Goeyens $L$, Lecomte $P$, Maghuin-Rogister $G$, Pironnet A, Pussemier L, Scippo M, Van Loco J, Covaci A. A review of dietary and non-dietary exposure to bisphenol-A. Food and Chemical Toxicology. 2012 Oct;50(10):3725-3740. https://doi.org/10.1016/j. fct.2012.07.059

8. Vandenberg LN, Chahoud I, Heindel JJ, Padmanabhan V, Paumgartten FJ, Schoenfelder G. Urinary, Circulating, and Tissue Biomonitoring Studies Indicate Widespread Exposure to Bisphenol A. Environmental Health Perspectives. 2010 Aug;118(8):1055-1070. https://doi.org/10.1289/ehp.0901716

9. La Merrill MA, Vandenberg LN, Smith MT, Goodson W, Browne P, Patisaul HB, Guyton KZ, Kortenkamp A, Cogliano VJ, Woodruff TJ, Rieswijk L, Sone H, Korach KS, Gore AC, Zeise L, Zoeller RT. Consensus on the key characteristics of endocrine-disrupting chemicals as a basis for hazard identification. Nature Reviews Endocrinology. 2019 Nov 12;16(1):45-57. https://doi.org/10.1038/s41574-019-0273-8

10. Zoeller RT, Brown TR, Doan LL, Gore AC, Skakkebaek NE, Soto AM, Woodruff TJ, Vom Saal FS. EndocrineDisrupting Chemicals and Public Health Protection: A Statement of Principles from The Endocrine Society. Endocrinology. 2012 Sep 1;153(9):4097-4110. https://doi.org/10.1210/en.2012-1422

11. Rutkowska A, Rachoń D, Milewicz A, Ruchała M, Bolanowski M, Jędrzejuk D, Bednarczuk T, Górska M, Hubalewska-Dydejczyk A, Kos-Kudła B, Lewiński A, Zgliczyński W. Polish Society of Endocrinology Position statement on endocrine disrupting chemicals (EDCs). Endokrynologia Polska. 2015;66(3):276-85. https://doi.org/10.5603/EP.2015.0035

12. Konduracka E, Krzemieniecki K, Gajos G. Relationship between everyday use cosmetics and female breast cancer. Polish Archives of Internal Medicine. 2014 Apr 2;124(5):264-269. https://doi.org/10.20452/ pamw. 2257

13. López-Carrillo L, Hernández-Ramírez RU, Calafat AM, Torres-Sánchez L, Galván-Portillo $\mathrm{M}$, Needham LL, Ruiz-Ramos R, Cebrián ME. Exposure to Phthalates and Breast Cancer Risk in Northern Mexico. Environ- 
mental Health Perspectives. 2010 Apr;118(4):539544. https://doi.org/10.1289/ehp.0901091

14. Rutkowska AZ, Szybiak A, Serkies K, Rachoń D. Endocrine disrupting chemicals as the potential risk factor for estrogen-dependent cancers. Polish Archives of Internal Medicine. 2016 Aug 9;. https:// doi.org/10.20452/pamw.3481

15. Mantzouki C, Bliatka D, lliadou PK, Margeli A, Papassotiriou I, Mastorakos G, Kousta E, Goulis DG. Serum Bisphenol A concentrations in men with idiopathic infertility. Food and Chemical Toxicology. 2019 Mar;125:562-565. https://doi.org/10.1016/j. fct.2019.02.016

16. Konieczna A, Rachoń D, Owczarek K, Kubica P, Kowalewska A, Kudłak B, Wasik A, Namieśnik J. Serum bisphenol A concentrations correlate with serum testosterone levels in women with polycystic ovary syndrome. Reproductive Toxicology. 2018 Dec;82:32-37. https://doi.org/10.1016/j.reprotox.2018.09.006

17. Wassenaar PNH, Trasande L, Legler J. Systematic Review and Meta-Analysis of Early-Life Exposure to Bisphenol A and Obesity-Related Outcomes in Rodents. Environmental Health Perspectives. 2017 Oct 3;125(10):106001. https://doi.org/10.1289/ ehp1233

18. Perera F, Nolte EL, Wang Y, Margolis AE, Calafat AM, Wang S, Garcia W, Hoepner LA, Peterson BS, Rauh V, Herbstman J. Bisphenol A exposure and symptoms of anxiety and depression among inner city children at 10-12 years of age. Environmental Research. 2016 Nov;151:195-202. https://doi.org/10.1016/j. envres.2016.07.028

19. Kitamura S. Comparative Study of the EndocrineDisrupting Activity of Bisphenol A and 19 Related Compounds. Toxicological Sciences. 2005 Jan 19;84(2):249-259. https://doi.org/10.1093/toxsci/ kfiO74

20. Chevrier J, Gunier RB, Bradman A, Holland NT, Calafat AM, Eskenazi B, Harley KG. Maternal Urinary Bisphenol A during Pregnancy and Maternal and Neonatal Thyroid Function in the CHAMACOS Study. Environmental Health Perspectives. 2013 Jan;121(1):138144. https://doi.org/10.1289/ehp.1205092

21. Moriyama K, Tagami T, Akamizu T, Usui T, Saijo M, Kanamoto N, Hataya Y, Shimatsu A, Kuzuya H, Nakao K. Thyroid Hormone Action Is Disrupted by Bisphenol A as an Antagonist. The Journal of Clinical Endocrinology \& Metabolism. 2002 Nov 1;87(11):51855190. https://doi.org/10.1210/jc.2002-020209

22. Lee S, Kim C, Youn H, Choi K. Thyroid hormone disrupting potentials of bisphenol $\mathrm{A}$ and its analogues - in vitro comparison study employing rat pituitary (GH3) and thyroid follicular (FRTL-5) cells. Toxicology in Vitro. $2017 \mathrm{Apr} ; 40: 297-304$. https://doi. org/10.1016/j.tiv.2017.02.004

23. Lee J, Kim S, Choi K, Ji K. Effects of bisphenol analogs on thyroid endocrine system and possible interaction with $17 \beta$-estradiol using GH3 cells. Toxicology in Vitro. 2018 Dec;53:107-113. https://doi. org/10.1016/j.tiv.2018.08.005

24. Higashihara N, Shiraishi K, Miyata K, Oshima $Y$, Minobe $Y$, Yamasaki K. Subacute oral toxicity study of bisphenol $\mathrm{F}$ based on the draft protocol for the "Enhanced OECD Test Guideline no. 407". Archives of Toxicology. 2007 Jul 13;81(12):825-832. https://doi. org/10.1007/s00204-007-0223-4

25. Zoeller RT, Bansal R, Parris C. Bisphenol-A, an Environmental Contaminant that Acts as a Thyroid Hormone Receptor Antagonist in Vitro, Increases Serum Thyroxine, and Alters RC3/Neurogranin Expression in the Developing Rat Brain. Endocrinology. 2005 Feb 1;146(2):607-612. https://doi.org/10.1210/en.20041018

26. Lee S, Kim C, Shin H, Kho Y, Choi K. Comparison of thyroid hormone disruption potentials by bisphenols $A, S, F$, and $Z$ in embryo-larval zebrafish. Chemosphere. 2019 Apr;221:115-123. https://doi. org/10.1016/j.chemosphere.2019.01.019

27. Völkel W, Colnot T, Csanády GA, Filser JG, Dekant W. Metabolism and Kinetics of Bisphenol A in Humans at Low Doses Following Oral Administration. Chemical Research in Toxicology. 2002 Oct;15(10):12811287. https://doi.org/10.1021/tx025548t

28. Andrianou XD, Gängler S, Piciu A, Charisiadis P, Zira C, Aristidou K, Piciu D, Hauser R, Makris KC. Human Exposures to Bisphenol A, Bisphenol F and Chlorinated Bisphenol A Derivatives and Thyroid Function. Carvalho DPD. PLOS ONE. 2016 Oct 26;11(10):e0155237. https://doi.org/10.1371/journal.pone.0155237

29. Calafat AM, Kuklenyik Z, Reidy JA, Caudill SP, Ekong J, Needham LL. Urinary Concentrations of Bisphenol $\mathrm{A}$ and 4-Nonylphenol in a Human Reference Population. Environmental Health Perspectives. 2005 Apr;113(4):391-395. https://doi.org/10.1289/ ehp.7534

30. Vandenberg LN, Hauser $R$, Marcus $M$, Olea $N$, Welshons WV. Human exposure to bisphenol A (BPA). Reproductive Toxicology. 2007 Aug;24(2):139-177. https://doi.org/10.1016/j.reprotox.2007.07.010

31. Schmutzler C, Bacinski A, Gotthardt I, Huhne K, Ambrugger $\mathrm{P}$, Klammer $\mathrm{H}$, Schlecht $\mathrm{C}$, Hoang-Vu $\mathrm{C}$, Grüters A, Wuttke W, Jarry H, Köhrle J. The Ultraviolet Filter Benzophenone 2 Interferes with the Thyroid Hormone Axis in Rats and Is a Potent in Vitro Inhibitor of Human Recombinant Thyroid Peroxidase. Endocrinology. 2007 Jun 1;148(6):2835-2844. https://doi.org/10.1210/en.2006-1280

32. Kudo Y. In Vitro and in Vivo Analysis of the Thyroid Disrupting Activities of Phenolic and Phenol Compounds in Xenopus laevis. Toxicological Sciences. 2005 Jan 5;84(1):29-37. https://doi.org/10.1093/tox$\mathrm{sci} / \mathrm{kfi0} 49$

33. Xu X, Liu Y, Sadamatsu M, Tsutsumi S, Akaike M, Ushijima $H$, Kato N. Perinatal bisphenol A affects the behavior and SRC-1 expression of male pups but does not influence on the thyroid hormone receptors and its responsive gene. Neuroscience Research. 2007 Jun;58(2):149-155. https://doi.org/10.1016/j. neures.2007.02.011

34. Nieminen $P$, Lindström-Seppä $P$, Juntunen $M$, Asikainen J, Mustonen A, Karonen S, Mussalo-Rauhamaa $\mathrm{H}$, Kukkonen $\mathrm{J}$. In vivo effects of bisphenol $\mathrm{A}$ on the polecat (mustela putorius). Journal of Toxicology and Environmental Health. Part A. 2002;65:933-45. 
35. Aung MT, Johns LE, Ferguson KK, Mukherjee $B$ McElrath TF, Meeker JD. Thyroid hormone parameters during pregnancy in relation to urinary bisphenol A concentrations: A repeated measures study. Environment International. 2017 Jul;104:33-40. https:// doi.org/10.1016/j.envint.2017.04.001

36. Romano ME, Webster GM, Vuong AM, Thomas Zoeller R, Chen A, Hoofnagle AN, Calafat AM, Karagas MR, Yolton K, Lanphear BP, Braun JM. Gestational urinary bisphenol $A$ and maternal and newborn thyroid hormone concentrations: The HOME Study. Environmental Research. 2015 Apr;138:453-460. https://doi. org/10.1016/j.envres.2015.03.003

37. Meeker JD, Ferguson KK. Relationship between Urinary Phthalate and Bisphenol A Concentrations and Serum Thyroid Measures in U.S. Adults and Adolescents from the National Health and Nutrition Examination Survey (NHANES) 2007-2008. Environmental Health Perspectives. 2011 Oct;119(10):1396-1402. https://doi.org/10.1289/ehp.1103582

38. Geens T, Dirtu AC, Dirinck E, Malarvannan G, Van Gaal L, Jorens PG, Covaci A. Daily intake of bisphenol A and triclosan and their association with anthropometric data, thyroid hormones and weight loss in overweight and obese individuals. Environment International. 2015 Mar;76:98-105. https://doi.org/10.1016/j. envint.2014.12.003

39. Minatoya M, Sasaki S, Araki A, Miyashita C, Itoh S, Yamamoto J, Matsumura T, Mitsui T, Moriya K, Cho K, Morioka K, Minakami H, Shinohara N, Kishi R. Cord Blood Bisphenol A Levels and Reproductive and Thyroid Hormone Levels of Neonates. Epidemiology. 2017 Oct;28:S3-S9. https://doi.org/10.1097/ ede. 0000000000000716

40. Derwahl M, Nicula D. Estrogen and its role in thyroid cancer. Endocrine Related Cancer. 2014 Jul 22;21(5):T273-T283. https://doi.org/10.1530/erc-140053

41. Klinge. Estradiol-induced proliferation of papillary and follicular thyroid cancer cells is mediated by estrogen receptors $\alpha$ and $\beta$. International Journal of Oncology. 2010 Mar 24;36(5). https://doi. org/10.3892/ijo_00000588

42. Liu J, Chen G, Meng X, Liu Z, Dong S. Serum levels of sex hormones and expression of their receptors in thyroid tissue in female patients with various types of thyroid neoplasms. Pathology - Research and Practice. 2014 Dec;210(12):830-835. https://doi. org/10.1016/j.prp.2014.09.002

43. Zhou Z, Zhang J, Jiang F, Xie Y, Zhang X, Jiang L. Higher urinary bisphenol A concentration and excessive iodine intake are associated with nodular goit- er and papillary thyroid carcinoma. Bioscience Reports. 2017 Jul 27;37(4). https://doi.org/10.1042/ bsr20170678

44. Marotta V, Russo G, Gambardella C, Grasso M, La Sala D, Chiofalo MG, D'Anna R, Puzziello A, Docimo G, Masone S, Barbato F, Colao A, Faggiano A, Grumetto L. Human exposure to bisphenol AF and diethylhexyIphthalate increases susceptibility to develop differentiated thyroid cancer in patients with thyroid nodules. Chemosphere. 2019 Mar;218:885-894. https:// doi.org/10.1016/j.chemosphere.2018.11.084

45. Li L, Ying Y, Zhang C, Wang W, Li Y, Feng Y, Liang J, Song $\mathrm{H}$, Wang $\mathrm{Y}$. Bisphenol $A$ exposure and risk of thyroid nodules in Chinese women: A case-control study. Environment International. 2019 May;126:321328. https://doi.org/10.1016/j.envint.2019.02.026

46. Wang $N$, Zhou $Y$, Fu C, Wang $H$, Huang $P$, Wang $B$, Su $M$, Jiang $F$, Fang $H$, Zhao $Q$, Chen $Y$, Jiang $Q$. Influence of Bisphenol A on Thyroid Volume and Structure Independent of lodine in School Children. Gao C. PLOS ONE. 2015 Oct 23;10(10):e0141248. https://doi. org/10.1371/journal.pone.0141248

47. Chailurkit L, Aekplakorn W, Ongphiphadhanakul B. The Association of Serum Bisphenol A with Thyroid Autoimmunity. International Journal of Environmental Research and Public Health. 2016 Nov 17;13(11):1153. https://doi.org/10.3390/ijerph13111153

48. Özaydın T, Öznurlu Y, Sur E, Çelik I, Uluışık D. The effects of bisphenol A on some plasma cytokine levels and distribution of CD8+ and CD4+ T lymphocytes in spleen, ileal Peyer's patch and bronchus associated lymphoid tissue in rats. Acta Histochemica. 2018 Nov;120(8):728-733. https://doi.org/10.1016/j. acthis.2018.08.002

49. Aljadeff G, Longhi E, Shoenfeld Y. Bisphenol A: A notorious player in the mosaic of autoimmunity. Autoimmunity. 2018 Nov 17;51(8):370-377. https:// doi.org/10.1080/08916934.2018.1551374

50. Kharrazian D. The Potential Roles of Bisphenol A (BPA) Pathogenesis in Autoimmunity. Autoimmune Diseases. 2014;2014:1-12. https://doi. org/10.1155/2014/743616

51. Jensen CD, Andersen KE. Two cases of occupational allergic contact dermatitis from a cycloaliphatic epoxy resin in a neat oil: Case Report. Environmental Health. 2003 Mar 26;2(1). https://doi. org/10.1186/1476-069x-2-3

52. Hannu T, Frilander $H$, Kauppi $P$, Kuuliala O, Alanko K. IgE-Mediated Occupational Asthma from Epoxy Resin. International Archives of Allergy and Immunology. 2009;148(1):41-44. https://doi. org/10.1159/000151504 